\title{
sciendo

\section{Integration of Sun PV Electricity in Centralized Heating Systems}

\author{
Marta DELLE ${ }^{1 *}$, Iveta CIVCISA ${ }^{2}$, Valdis VITOLINS ${ }^{3}$, Dace LAUKA ${ }^{4}$, \\ Dagnija BLUMBERGA ${ }^{5}$ \\ ${ }^{1-5}$ Institute of Energy Systems and Environment, Riga Technical University, \\ Azenes iela 12/1, Riga, LV-1048, Latvia
}

\begin{abstract}
During the experimental research, an algorithm was developed as a guide for the introduction of solar panels (PV) in centralized heat supply (CHS) companies and a SWOT analysis of the developed algorithm action blocks was performed. SWOT analysis was carried out for a project implemented in practise and, as a result of which the centralized heat supply system uses solar power with a total capacity of $30 \mathrm{~kW}$. We found that in Latvia, the areas that are suitable for solar panels are several times higher than those required by the systems. Main tasks of the work: to analyse and study available literature and information on solar PV integration into CHS; analyse available solar PV power generation equipment and technologies; develop a roadmap for easy and understandable deployment of solar panels in the company.
\end{abstract}

Keywords - Centralized heating; PV panels; solar energy

\section{INTRODUCTION}

The theme of the research is linked to one of the main objectives of the European Union, which is to reduce the greenhouse effect (reduce emissions responsible for global warming) and increase use of renewable resources. Europe is constantly striving to achieve this goal in the year 2016 around $90 \%$ of all new capacity connected to Europe's electricity grid came directly from renewable energy sources, but at the same time most of the European electricity grid is still working on fossil fuels [1].

Theoretically, there is a belief that the potential of solar energy is large enough to meet the global energy demand. It is inexhaustible, ecologically clean and does not create additional waste in nature. Solar energy technologies and the related industry are developing globally thanks to high demand for energy, limitations of fossil resources and expensive price for alternatives.

Although the energy sector in Latvia is well developed and renewable energy is mostly used for electricity generation in comparison with the use of biomass and hydroelectric power stations (HES), unfortunately the use of solar energy and its panel systems is still lagging behind. The Central Statistical Bureau of Latvia does not show solar energy in the total energy consumption of the country, as it is less than $0.1 \%$, but the potential for this sector in Latvia is great, for example, countries like Germany and Denmark, where climatic conditions and

\footnotetext{
* Corresponding author.

E-mail address: dellemarta@gmail.com
} 
average solar radiation are similar as in Latvia, they are among the world's leading users of solar panel systems [1].

Both renewable energy production and consumption in the EU and Latvia are increasing, but there is a need to continue to work towards the EU target of increasing the share of energy from renewable sources in final energy consumption from $20 \%$ in 2020 to at least $27 \%$ by 2030 year [2].



Fig. 1. Trends in the share of RES in Latvia from the years 2012-2017 [3].

Statistics include all renewable energy resources (see Fig. 1) and a slow increase was observed. This is due to insufficient state support. When analysing the statistics, there are clearly years of support whereby EU funds have been allocated for the introduction of renewable energy resources and the replacement of fossil resources with renewables.

\section{Solar Energy Potential}

Solar energy is derived from the sun and is one of the foundations of life on earth. The solar energy absorbed by the earth every hour is greater than the total energy consumption on the ground during the year. Currently, the world's solar energy makes up only $0.1 \%$ of the total energy production. The use of solar energy in the world has the greatest theoretical potential. The radiation received by the Earth's surface is thousands of times the world's energy demand. Solar energy is an inexhaustible source of energy that continuously radiates to the earth in daylight. Solar energy is a very safe source of energy from the investment point of view, because it is not predicted to disappear in the foreseeable future and this type of energy will become the main source of energy due to its potential and benefits.

It is important that solar cells or solar collectors have practically no maintenance and service costs. Solar energy can be used in a passive or active way. The passive use of solar energy is, for example, the use of daylight in buildings. Use of solar heat directly - through windows and/or by choosing building facade materials that effectively accumulate the heat received. Passive solar energy is usually utilized through various design and architectural solutions. In contrast, active technologies use solar energy to accumulate or transform it. Active technologies are divided into two groups - photovoltaic (PV) for electricity generation and thermal technology for thermal energy production [4]. 


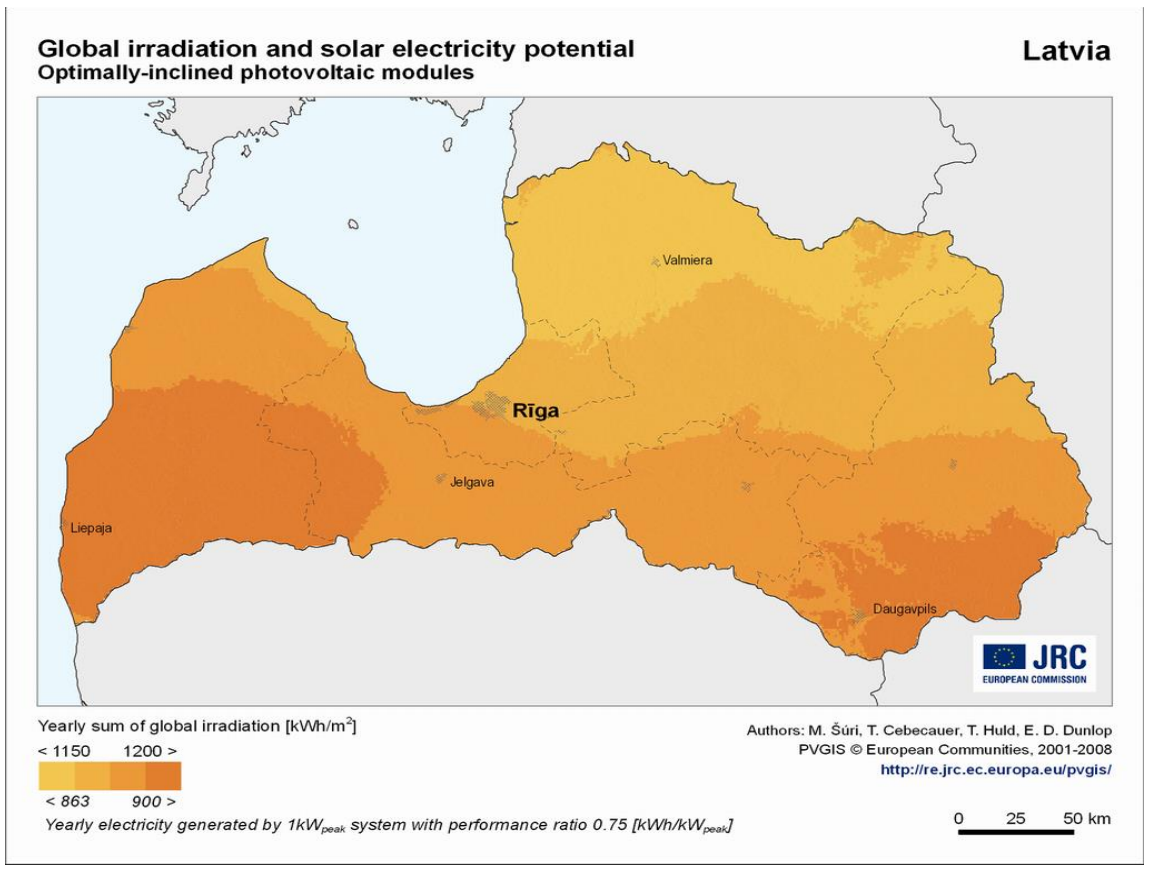

Fig. 2. Solar radiation and solar potential in Latvia [5].

Solar panel technologies available on the Latvian market are determined by cell type monocrystalline, polycrystalline and thin films. Monocrystalline and polycrystalline panels are capable of converting up to $20 \%$ of solar radiation into electricity, but they have high production costs because the operation of these panels requires high quality silicon with a perfect crystalline structure [6], which is the main reason for replacing these panels. Thin film panels are comparatively cheaper due to cost and efficiency of production. To obtain $1 \mathrm{~kW}$ of electricity under standard conditions $\left(25^{\circ} \mathrm{C}, 1000 \mathrm{~W} / \mathrm{m}^{2}\right)$, such panels should be cover $10-$ $15 \mathrm{~m}^{2}$ of a roof's territory, while crystalline silicon panels under these conditions need to cover approximately 7-8 $\mathrm{m}^{2}$ of a roof [6], [7]. Both of these panels are now guaranteed a lifetime of 25 to 30 years, and maintenance costs are minimal. Due to the low efficiency of thin film panels and the high price of monocrystalline panels, polycrystalline solar panels dominate the Latvian and world markets.

\section{NET Settlement Principle}

Solar panel systems in Latvia operate on the Net Settlement principles (see Fig. 3). The energy produced by the panels comes first into the inverter, where galvanic curre nt is converted to alternating current (AC). Subsequently, the alternating current enters the power distributor, where the necessary energy is passed to the consumer, while the remaining energy enters the meter which it transfers into the Distribution Network. The principle of net settlement is that the amount of energy entered into the network can be recovered when the need arises for a special tariff price [8]. The first alternative, if the electricity consumption exceeds the solar panel production, it is possible to purchase electricity from the public network at a standard 
price. The second alternative, if the electricity consumption exceeds the production of solar panels, it is possible to use it in the production of heat for heating the heat carrier.

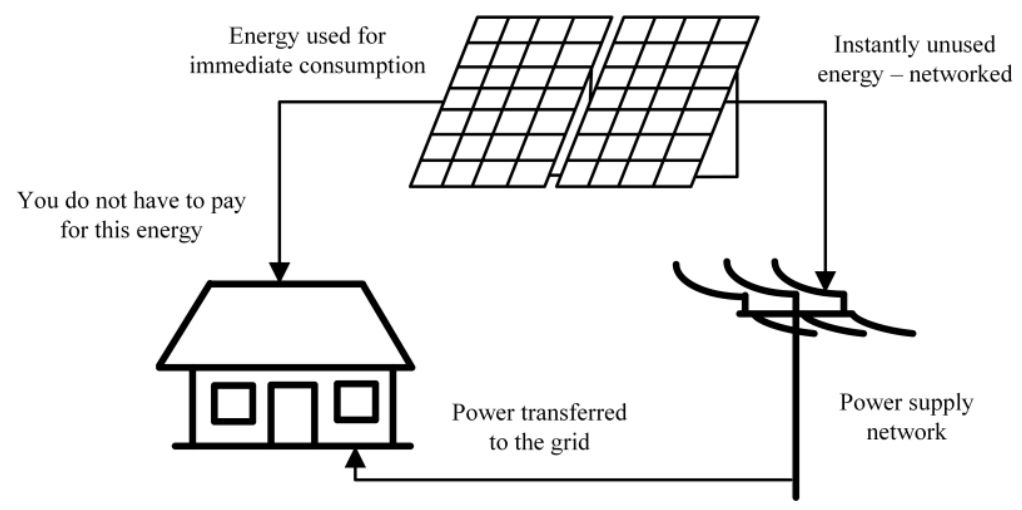

Fig. 3. Net settlement principle [8].

\section{Development of Solar Panel Systems in Latvia}

The average solar gain in Latvia is $1000-1200 \mathrm{kWh} / \mathrm{m}^{2}$ [9] (see Fig. 2), which is very similar to countries like Germany and Denmark, which are the world's leading users of solar panel systems, for example, Germany in 2015 generated $16 \%$ or $39.6 \mathrm{GW}$ of the total installed solar power in the world [6], so the climatic conditions of Latvia are not an obstacle to the use of its solar potential. There is a relatively large bureaucracy in Latvia for coordinating solar panel installation with the related state institutions, which could prevent people from using them. In order to successfully install a solar panel system in a household, the consumer must coordinate this process with the Ministry of Economics, the building board and the Distribution Network (JSC "Sadales Tikls"). On average, this installation process may take up to three months in Latvia [9]. Another factor in which the use of solar panels in Latvia is lagging behind is the high starting capital costs. Depending on the capacity and accumulation method of the solar panel system, the average starting cost of 15 households that were included in the research in Latvia, was EUR 5000 [1], and it is considered that the investment is beneficial if it pays within 5 years, which did not work in any of these Latvian households under the given conditions. This can be based on the fact that people in Latvia do not yet have the most efficient solar panel technology available, on average these efficiency ratios show $16.92 \%$ for panels in Latvia, and the panels themselves in Latvia can cost even twice as much as in other European countries due to low demand [1]. However, the most important reason why this energy sector has not yet fully developed in Latvia (which also plays a major role in Germany and Denmark's use of solar panels) is the lack of political support and national-level initiatives [10]. Unlike other European countries, there are no financially mitigating conditions for green energy users in Latvia. However, there are periodically extensive discussions about the possibility of transferring electricity produced in households to the common electricity grid at more favourable procurement rates, thereby stimulating the use of solar technologies in Latvia. In Latvia, there is no political will to actively stimulate the use of renewable energy assets.

The number of permits issued by the Ministry of Economics for the installation of solar panels from 2015 to January 2018 was 333 licences, i.e. 83 in 2015, 85 in 2016 and 157 in 2017 [9], so it can be seen that the popularity of this technology in Latvia has increased in recent years. Latvia is also home to one of the first and largest solar power plants in the Baltic 
countries. It is the 216-panel and 42-kilowatt-powered "Sunshine Gardens" ("Saules Darzs") in Salacgriva, the Dune Manor Minhauzen Museum in Dunte, where since 2012 the electricity-powered power plant supplies the museum's information centre and adjacent pub with electricity, but the electricity surplus enters the JSC "Sadales Tikls" (distribution network) [11]. On average, the Dunte power plant is capable of producing $45 \mathrm{MWh}$ per year and, as a result, the amount of $\mathrm{CO}_{2}$ emissions in the atmosphere has decreased by 23.03 tonnes, which is important for reducing $\mathrm{CO}_{2}$ emissions in Latvia [12]. Currently, only two centralised heating companies in Latvia have installed solar power panels ("Salaspils Siltums", Ltd. "Jurmalas Siltums"). When planning the total capacity of the solar power panels, the main condition is that panel performance does not exceed the company's electricity self-consumption. On the roof of "Salaspils Siltums" building there are 86 solar panels with a total capacity of $25 \mathrm{~kW}$ and a total active area of $137.6 \mathrm{~m}^{2}$. Solar panels were installed in August 2017. In 2018, 26.32 MWh were produced.

\section{Legislation OF Renewable Solar EnERgy USE in District Heating SYSTEMS}

The European Union has set targets for reducing greenhouse gas emissions for certain economic sectors. To prevent dangerous climate change, within the framework of the Paris Climate Agreement, EU leaders have agreed on EU binding targets to reduce greenhouse gas emissions by at least $40 \%$ by 2030 compared to 1990 levels. In November 2018, the European Commission presented a strategic long-term vision for a climate-neutral economy by 2050 , mentioning 8 possible development scenarios. EU leaders adopted the strategy at their European Council meeting in May 2019. The European Parliament voted on its recommendations for the strategy on 14 March 2019 [13]. Latvian companies will be forced to take part in addressing the challenges of change by using more environmentally friendly technologies and consumer behaviour should be taken into account [14]. District heating offers the most effective way to enhance the efficiency of primary energy use, increasing the share of renewable energy consumption and decreasing the amount of $\mathrm{CO}_{2}$ emissions [15].

Strategic policy documents "Energy Development Guidelines for 2016-2020" [16] with "Long-term Energy Strategy for Latvia 2030 - Competitive Energy for Society" outline the long-term development trends of the energy sector. The guidelines describe actions, considering the following climate and energy policy objectives set by the European Council in March 2007 and to be achieved by the European Union (EU) by 2020:

- $20 \%$ reduction in greenhouse gas (GHG) emissions compared to 1990 levels;

- Increasing the share of renewable energy in total consumption to $20 \%$;

- Increase energy efficiency by $20 \%$.

Financing from the national or local government budget, EU funds, the Connecting Europe Facility, as well as from capital companies is envisaged for the implementation of the measures included in the Guidelines for the year 2020. The documents describe the financial instruments for implementing energy development guidelines, but in reality, the situation is a bit different. Primarily the producer of thermal energy is regulated by the Law on Energy and the Law "On Public Utilities Regulators", as well as the Law on the Management of Capital Shares and Capital Companies of a Public Person, if the heat producer is a corporation. The bureaucratic process is so complicated and lengthy that document management, often for the purpose of acquiring EU funds, takes longer than the actual implementation of a project. 


\section{SOLAR INTEGRATION IN JURMALA MUNICIPALITY}

The district heating company of Jurmala City Municipality provides heat production, including maintenance, supply and sale of boiler houses to residents, enterprises and municipal institutions. The Company manages 14 boiler houses, 12 natural gas boiler houses and two chips boiler houses with a total installed capacity for heat production of 88.03 MW, and in 2018 supplied heat energy to 349 objects in Jurmala. In order to reduce heat losses in production, the modernization and reconstruction of boiler houses is performed. Boiler houses are equipped with a modern remote control program that allows you to keep track of the operation of the boiler house from any place and adjust the parameters. Chip boiler house equipment and the most important assistant technologies are controlled with a remote control program that accumulates all information about processes and ensures their visualization. Visualization for a boiler operator facilitates monitoring of processes. On March 26 last year, the Jurmala City Municipality Heat Supply Company in the Ministry of Economics signed a voluntary agreement on improving energy efficiency. By signing such an agreement, the Jurmala City Municipality Heat Supply Company has set a target to achieve final energy consumption savings of $10 \%$ of the amount of heat sold by the company over the last three years until the end of March 2023. Energy savings are designed to be achieved using different methods. One of the key tasks of the agreement is to promote the improvement of energy efficiency in Jurmala City Municipality heat supply company, but the most important goal of the voluntary agreement is to fulfil the goals set at the national level in the Energy Development Guidelines 2016-2020.

In addition, Ltd. "Jurmalas Siltums" is actively carrying out research on the possibilities of integrating other renewable energy resources in the Jurmala city heat supply company. Since 2018, the company has been active in the installation of a solar power plant with a nominal capacity of $30 \mathrm{~kW}$ on the roof of the boiler house at Slokas iela 47A.

After the installation of the solar power plant, Ltd. "Jurmalas Siltums" uses electricity from two sources in the internal electricity networks - from the distribution network and from the solar plant. Both energy sources are interconnected through the Ltd. "Jurmalas Siltums" power network. Ltd. "Jurmalas Siltums" solar power plant generates electricity by synchronizing with JSC "Sadales Tikls" parameters and "Jurmalas Siltums" energy consumers can receive electricity simultaneously from two sources of energy, primarily using the energy produced by all solar panels, but if they are lacking, additionally from the "Sadales Tikls" electricity grid. Only in cases when consumption is less than that produced by solar panels, unused electricity flows into the "Sadales Tikls" grid and are accounted for as energy exports.

Thus, reducing energy imports from "Sadales Tikls", the cost of the company decreases and the value of the solar panel energy is equal to the total energy price from "Sadales Tikls" (electricity price + ST service charge + mandatory procurement component $(\mathrm{OIK}))-0.09 \mathrm{EUR} / \mathrm{kWh}$.

In turn, by transferring energy surplus to the "Sadales Tikls" network, the electricity trader buys it for the price of electricity $(0.04 \mathrm{Eur} / \mathrm{kWh})$. This means that the return on investment is considerably shorter if all the electricity produced is consumed at the same time. Installing a power plant that would exceed the minimum power consumption would result in a surplus of electricity that should be sold at a lower price and payback times increase. Therefore, when analysing the dynamics of electricity consumption, Jurmala has chosen to install a solar power plant with a capacity of $30 \mathrm{~kW}$, which is close to, but does not exceed minimum electricity consumption (see Fig. 4). 


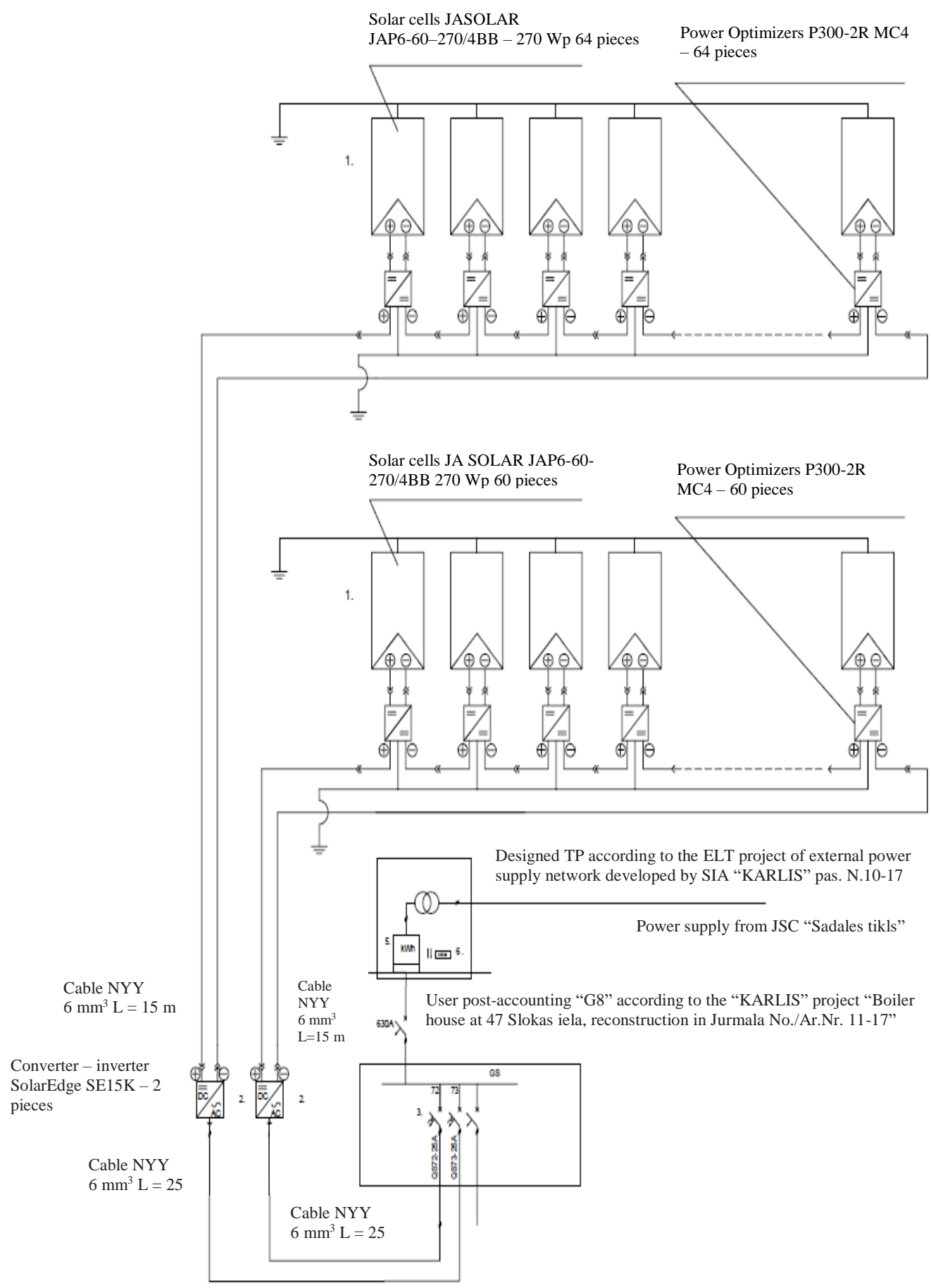

Fig. 4. Connection scheme of solar power plant with nominal capacity $30 \mathrm{~kW}$ for parallel operation with JSC "Sadales Tikls" electricity network. 


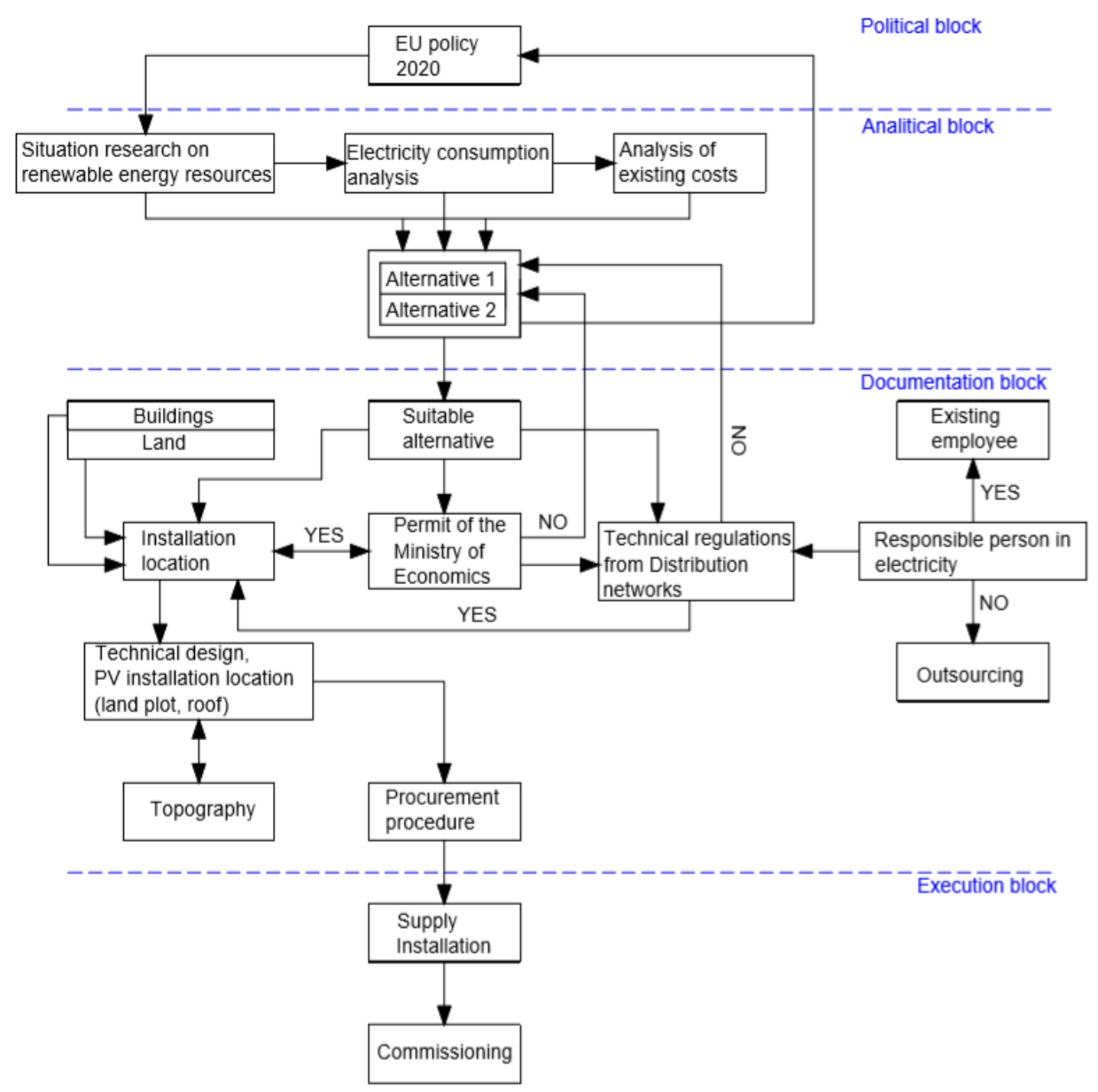

Fig. 5. Analytical algorithm for solar PV panel implementation.

\section{Methodology GUIDE FOR The IMPlementation OF THE SUN PANEL}

The algorithm is divided into four blocks (see Fig. 5): the policy block; analytical block, documentation block, execution block.

Policy block: district heating is an energy sector regulated by the Government, and Governments, in turn, integrate regulations which are negotiated and agreed upon among EU countries within the EU, which include energy efficiency requirements, availability and environmentally friendly heat production. Each municipality organizes district heating in its administrative territory.

Block of analysis: considering the common state and European Union policies and objectives, the company conducts theoretical research on the possibilities of introducing renewable energy resources in a district heating company [17].

Documentation block: when choosing the appropriate alternative, the company must make a decision about where the solar panels will be placed (roof or on the ground-level). If parts 
of the building supporting structure (roof, walls) are chosen as the place of project implementation, it is necessary to plan the development of a full technical project. Regardless of the chosen location of the project, it is necessary to order current topography of the area. In order to implement the project, a permit from the Ministry of Economics is required. At the same time, it is necessary to receive technical regulations from JSC "Sadales Tikls". JSC "Sadales Tikls" will not issue technical regulations if the company does not specify the responsible person for the electrical management with the appropriate qualifications (if there is no specialist, an outsourcing contract has to be concluded). When technical regulations and the permission of the Ministry of Economics have been approved, the project's development and procurement procedure can commence.

Execution block: signing contract for solar panel installation. Install solar panels. Preparation of documentation and operation of solar panels in cooperation with JSC "Sadales Tikls" and, if necessary, the municipal building board.

TABLE 1. TIME REQUiRED TO INSTALL SOLAR PANELS

\begin{tabular}{|c|c|}
\hline Actions/Documents for $30 \mathrm{~kW}$ PV panels & $\begin{array}{l}\text { Time for } \\
\text { implementation }\end{array}$ \\
\hline Technical and financial analysis of the company & 3 weeks \\
\hline $\begin{array}{l}\text { Documents certifying property rights } \\
\text { (Land Register Certificate, Land Boundary Plan) }\end{array}$ & 1 day \\
\hline $\begin{array}{l}\text { Application to the Ministry of Economics for permission to increase electricity } \\
\text { production capacities or implementation of new production equipment based on } \\
\text { Cabinet of Ministers Regulation No. } 883 \text { of } 11 \text { August } 2009 \text { "Regulations } \\
\text { Regarding Permits for Increasing Electricity Production Capacity or } \\
\text { Introduction of New Production Equipment" point No. } 2\end{array}$ & $2-4$ weeks \\
\hline Request and receive technical regulations from JSC "Sadales Tikls" & 4 weeks \\
\hline Development of a topographic plan & 4 weeks \\
\hline $\begin{array}{l}\text { Design started (if PV constructions are placed on the load-bearing structures of } \\
\text { the building, at least } 6 \text { extra weeks must be provided for project examination) }\end{array}$ & 4-6 months \\
\hline $\begin{array}{l}\text { Design consists of: } \\
\text { - Receiving technical regulations } \\
\text { - Preparing technological solutions } \\
\text { - Developing an economic section }\end{array}$ & \\
\hline Procurement process & 6 weeks \\
\hline Equipment delivery and installation & $2-3$ months \\
\hline Equipment inspection and commissioning & 4 weeks \\
\hline
\end{tabular}

Table 1 demonstrates that installing solar panels in a district heating company takes 10-12 months. During this time, it is possible to implement the project if several activities are performed simultaneously.

\section{SWOT ANALYSIS For InTEgration of SOlaR PANEls Into Heat SUPPLY SYSTEM}

SWOT analysis is the most commonly used method for analysing and positioning organizational resources and environment in four aspects: strengths, weaknesses, opportunities and threats [18]. Strengths and weaknesses are internal (controllable) factors 
that support and prevent organizations from achieving their mission and opportunities and threats are external (uncontrollable) factors that allow and disable organizations in their tasks [19]. By identifying factors in these four areas, an organization can recognize its key competencies in decision-making, planning and building strategies.

TABLE 2. SWOT ANALYSIS OF “ALGORITHM FOR

SOLAR PV PANEL IMPLEMENTATION” POLICY BLOCK

\begin{tabular}{|c|c|}
\hline Internal areas & Factors \\
\hline Opportunities: $(\mathrm{O})$ & $\begin{array}{l}\text { Main objectives of the European Union, which are the } \\
\text { reduction of greenhouse effect, that is, to reduce global } \\
\text { warming gas emissions and to increase use of renewable } \\
\text { energy resources }\end{array}$ \\
\hline Threats: (T) & $\begin{array}{l}\text { Republic of Latvia adopts laws without consultations, } \\
\text { fact-based thinking and without considering all interested } \\
\text { parties. This can negatively affect businesses }\end{array}$ \\
\hline \multirow[t]{3}{*}{ Strengths: (S) } & Experience and competence of employees \\
\hline & Stable financial situation \\
\hline & All the necessary certificates and permits \\
\hline \multirow[t]{2}{*}{ 1. How to use opportunities? (S.O.) } & $\begin{array}{l}\text { Using the qualification level of the employees can benefit } \\
\text { the process of reaching the set goals for the company }\end{array}$ \\
\hline & $\begin{array}{l}\text { Resources available to the company, as well as certificates } \\
\text { and permits, make it easier to leverage EU funds and act to } \\
\text { reduce the greenhouse effect }\end{array}$ \\
\hline 2. How to reduce or avoid threats? (S.T.) & $\begin{array}{l}\text { Introduce the ISO } 5001 \text { Energy Management System with } \\
\text { allows to react to changes and all interested parties } \\
\text { according to "good management" practices }\end{array}$ \\
\hline \multirow[t]{3}{*}{ Weaknesses: (W) } & $\begin{array}{l}\text { Relatively week effect on the Government's regulatory act } \\
\text { procedures and the process of regulation's adoption }\end{array}$ \\
\hline & $100 \%$ owned by the municipality \\
\hline & $\begin{array}{l}\text { Regulated related services and other interested party } \\
\text { activities, no possibilities to affect other stakeholders }\end{array}$ \\
\hline \multirow[t]{2}{*}{$\begin{array}{l}\text { 3. How market opportunities can help } \\
\text { overcome weaknesses? (W.O.) }\end{array}$} & $\begin{array}{l}\text { Using company engagement in associations, actively } \\
\text { participate in the preparation of the relevant normative acts }\end{array}$ \\
\hline & $\begin{array}{l}\text { Fossil fuels can be reduced and RES can be implemented } \\
\text { through EU funds }\end{array}$ \\
\hline \multirow{2}{*}{$\begin{array}{l}\text { 4. How to avoid threats and level out } \\
\text { weaknesses? (W.T.) }\end{array}$} & Actively participate in discussions on regulatory changes \\
\hline & $\begin{array}{l}\text { Opportunities to offer new, innovative services and } \\
\text { products }\end{array}$ \\
\hline
\end{tabular}

Summarizing the SWOT analysis data for the policy block of the algorithm (see Table 2), it can be concluded that the company has several options that can be used, for example, use employee qualifications and experience, engage in policy planning through relevant associations, improve and analyse the business of the company with regard to planned policy documents, such as the introduction of the ISO 5001 energy management system. The resources available to the company, as well as certificates and permits, make it easier to attract EU co-financing. 


\section{TABLE 3. SWOT ANALYSIS OF "ALGORITHM FOR SOLAR PV PANEL IMPLEMENTATION" ANALYTICAL BLOCK}

\begin{tabular}{|c|c|}
\hline Internal areas & Factors \\
\hline \multirow[t]{4}{*}{ Opportunities: (O) } & $\begin{array}{l}\text { Development and modernization of technologies for the integration } \\
\text { of RES into existing systems }\end{array}$ \\
\hline & $\begin{array}{l}\text { Improvement/Arrangement of the Jurmala heat supply area, } \\
\text { expansion }\end{array}$ \\
\hline & $\begin{array}{l}\text { A larger proportion of the population in the district is connected to } \\
\text { central heating }\end{array}$ \\
\hline & Attract EU funds to development projects \\
\hline \multirow[t]{6}{*}{ Threats: (T) } & $\begin{array}{l}\text { Threat of substitutes (introduction of different types of alternative } \\
\text { heating, such as solar) }\end{array}$ \\
\hline & Decrease in the number of residents (customers) \\
\hline & $\begin{array}{l}\text { Negative impact of political processes and natural disasters on } \\
\text { production prices and energy production industry }\end{array}$ \\
\hline & Decrease in population solvency \\
\hline & $\begin{array}{l}\text { Renovation of the buildings will reduce the heat load and increase } \\
\text { tariffs for thermal energy }\end{array}$ \\
\hline & Limit of EU funds \\
\hline \multirow[t]{4}{*}{ Strengths: (S) } & High qualification of employees \\
\hline & $\begin{array}{l}\text { Quality of services offered and responsibility for timely delivery of } \\
\text { services provided }\end{array}$ \\
\hline & Company's good reputation among existing consumers and partners \\
\hline & Stable financial situation \\
\hline \multirow[t]{3}{*}{$\begin{array}{l}\text { 1. How to use opportunities? } \\
\text { (S.O.) }\end{array}$} & $\begin{array}{l}\text { Attract new customers through good reputation and employee } \\
\text { qualification levels }\end{array}$ \\
\hline & Maintain good reputation by improving technological capabilities \\
\hline & $\begin{array}{l}\text { Resources available to the company, as well as certificates and } \\
\text { permits, make it easier to leverage EU funds and integrate RES } \\
\text { facilities into existing heating systems }\end{array}$ \\
\hline \multirow{4}{*}{$\begin{array}{l}\text { 2. How to reduce or avoid } \\
\text { threats? (S.T.) }\end{array}$} & Improve the quality of service provided \\
\hline & Overcome substitutes \\
\hline & $\begin{array}{l}\text { Employee qualification and product quality will keep existing } \\
\text { customers }\end{array}$ \\
\hline & $\begin{array}{l}\text { Stable financial situation and the unrestrained integration of RES } \\
\text { equipment into existing systems makes it possible to build up } \\
\text { reserves }\end{array}$ \\
\hline \multirow[t]{4}{*}{ Weaknesses: (W) } & Relatively high heat losses, long tracks \\
\hline & Most boiler houses use natural gas \\
\hline & High depreciation of existing fixed assets \\
\hline & High level of public debt \\
\hline \multirow{3}{*}{$\begin{array}{l}\text { 3. How market opportunities } \\
\text { can help overcome } \\
\text { weaknesses? (W.O.) }\end{array}$} & $\begin{array}{l}\text { Reduce heat loss through new technologies and infrastructure } \\
\text { improvements }\end{array}$ \\
\hline & $\begin{array}{l}\text { Technologically developing and reducing losses, as well as attracting } \\
\text { new customers, may increase net turnover }\end{array}$ \\
\hline & Using EU funds can replace the use of natural gas with RES \\
\hline \multirow[t]{3}{*}{$\begin{array}{l}\text { 4. How to avoid threats and } \\
\text { level out weaknesses? (W.T.) }\end{array}$} & $\begin{array}{l}\text { Increasing the cost of raw materials and high heat losses can have a } \\
\text { significant impact on the company's operations, but can be offset by } \\
\text { renewing technologies and introducing RES options }\end{array}$ \\
\hline & Net turnover and decrease in population will cause the company losses \\
\hline & Opportunities for offering new services and products \\
\hline
\end{tabular}


The SWOT analysis shows that the company can use its various strengths to mitigate its weaknesses, for example by improving existing infrastructure so that it can integrate RES to reduce fossil fuels, heat losses (see Table 3). An environmentally friendly and secure company will create the opportunity to attract new customers who will naturally improve the company's net turnover and reputation. By actively participating in the use of EU funds, it is possible to replace gas-fired houses with biomass boiler houses. Selling surplus emission allowances during the planning period allows a large part of the electricity used in the company to be produced by solar photovoltaic panels.

TABLE 4. SWOT ANALYSIS OF “ALGORITHM FOR SOLAR PV PANEL IMPLEMENTATION” DOCUMENTATION BLOCK

\begin{tabular}{|c|c|}
\hline Internal areas & Factors \\
\hline Opportunities: (O) & $\begin{array}{l}\text { There are several options for choosing the right RES alternative, } \\
\text { or for implementing several alternatives simultaneously }\end{array}$ \\
\hline \multirow[t]{3}{*}{ Threats: (T) } & Refusal of the Ministry of Economics \\
\hline & Technical regulations of JSC "Sadales Tikls" \\
\hline & Municipal refusal to implement the project \\
\hline \multirow[t]{3}{*}{ Strengths: (S) } & $\begin{array}{l}\text { Ownership of the property in which it is planned to implement } \\
\text { the projects for RES }\end{array}$ \\
\hline & Stable financial situation \\
\hline & Qualified staff \\
\hline \multirow[t]{2}{*}{$\begin{array}{l}\text { 1. How to use opportunities? } \\
\text { (S.O.) }\end{array}$} & $\begin{array}{l}\text { Using qualification levels of employees, it is possible to } \\
\text { implement several stages simultaneously }\end{array}$ \\
\hline & $\begin{array}{l}\text { Resources available to the company, as well as certificates and } \\
\text { permits, and collaboration allow you to get the required } \\
\text { permissions faster }\end{array}$ \\
\hline $\begin{array}{l}\text { 2. How to reduce or avoid } \\
\text { threats? (S.T.) }\end{array}$ & $\begin{array}{l}\text { As the fees and prices of the product and services can change it } \\
\text { is important to timely promulgate procurement process and } \\
\text { conduct market feasibility studies in related period of time }\end{array}$ \\
\hline \multirow[t]{2}{*}{ Weaknesses: (W) } & Company is $100 \%$ owned by the municipality \\
\hline & $\begin{array}{l}\text { Regulated services and activities that may interfere with the } \\
\text { introduction of new technologies in the company }\end{array}$ \\
\hline $\begin{array}{l}\text { 3. How market opportunities } \\
\text { can help overcome } \\
\text { weaknesses? (W.O.) }\end{array}$ & $\begin{array}{l}\text { Submit procurement documentation and get permissions } \\
\text { simultaneously }\end{array}$ \\
\hline $\begin{array}{l}\text { 4. How to avoid threats and } \\
\text { level out weaknesses? (W.T.) }\end{array}$ & $\begin{array}{l}\text { Perform analysis and feasibility studies before project } \\
\text { implementation }\end{array}$ \\
\hline
\end{tabular}

In the SWOT analysis in the Documentation Block (see Table 4) it became clear that the company has to carry out a deep feasibility study when starting the practical implementation of the project, the biggest risk is the municipality's refusal to implement the project, which the company can prevent by receiving the municipal permit already at the stage of the analytical block. 
TABLE 5. SWOT ANALYSIS OF “ALGORITHM FOR

SOLAR PV PANEL IMPLEMENTATION” EXECUTION BLOCK

\begin{tabular}{ll}
\hline Internal areas & Factors \\
\hline Opportunities: (O) & $\begin{array}{l}\text { Choose the appropriate RES alternative, or the implementation } \\
\text { of several alternatives at the same time }\end{array}$ \\
Equipment delivery and assembly compliance \\
JSC "Sadales Tikls" negative opinion about installed photovoltaic \\
panels
\end{tabular}

In the SWOT analysis of the Execution Block (see Table 5), the authors of the work observed:

- To avoid the biggest risks in this part of the project, the company should provide necessary training for additional staff members or contract outsourcing companies;

- The company has to carry out a deep feasibility study before starting practical implementation of the project;

- Instructing specialists of JSC "Sadales Tikls" in the period of project execution, the company eliminates the threat of technical acceptance of equipment.

\section{Conclusions}

1. RES takes a relatively small part of total CHS thermal energy balance. According to national and regional objectives, a target is developed to increase the shares of RES to $60 \%$ in local systems and to $30 \%$ in CHS. Firstly, the procedure for implementing RES should be arranged and facilitated. Secondly, the use of solar energy, biomass and geothermal energy should be increased;

2. It is necessary to stimulate new customers to connect to efficient district heating systems, as well as to limit the installation of autonomous fossil heating systems in areas where CHS is available. Develop an efficient CHS infrastructure suitable for the use of all RES energy. Considering the national and EU-wide RES targets and the fact that fossil energy resources are widely used in Latvia for the production of thermal energy, in the medium term (up to 2020) the Government should apply the aid exception for this specific goal and provide direct, high-intensity support to district 
heating systems for the transition to RES. Also introduce requirements and support mechanisms to promote the use of RES technologies in new and renovated buildings to promote the integration of new RES systems into district heating systems;

3. As a matter of urgency, review and facilitate the bureaucratic burden for RES introduction in central heating companies. Identify new support programs for improving the energy efficiency of a district heating system and the use of local renewable energy resources (RES);

4. Summarizing the SWOT analysis data, it can be concluded that the company has several options that can be used, for example, using the level of skills and experience of the employees to engage in policy planning through relevant associations, developing and analysing the company's performance with regard to planned policy documents, for example, the introduction of the ISO 5001 energy management system. The resources available to the company, as well as certificates and permits, make it easier to attract EU funds for co-financing, which facilitates the adaptation of infrastructure to the use of renewable energy resources.

\section{Suggestions}

1. To combine the permission of the Ministry of Economics with the technical regulation form of JSC "Sadales Tikls", because identical data are submitted to these organizations, thus the implementation time would be accelerated by one month;

2. Municipalities should develop an air pollution map of the central heating zones;

3. Implement binding rules in municipalities that would severely limit the development of individual fossil heating systems in new buildings, located in district heating zones;

4. Significantly increase the natural resource tax on fossil fuels;

5. Ministry of Environment and Regional Development and Ministry of National Defence should create air pollution zoning map in all major cities. When designing this zoning map, air pollution caused by decentralized heat supply should be taken account;

6. The Ministry of Economics should develop a methodology and issue an order that the production companies could receive electricity back from JSC "Sadales Tikls" without paying feed-in tariff.

\section{ACKNOWLEDGEMENT}

This research is funded by the Ministry of Economics of the Republic of Latvia, project "Development of heat supply and cooling systems in Latvia”, project No. VPP-EM-EE-2018/1-0002.

\section{REFERENCES}

[1] Rozentale L., Lauka D., Blumberga D. Accelerating power generation with solar panels. Case in Latvia. Energy Procedia 2018:147:600-606. doi:10.1016/j.egypro.2018.07.077

[2] European Court of Auditors [Online]. [Accessed 02.05.2019]. Available: https://www.eca.europa.eu/Lists/ECADocuments/SR18_05/SR_Renewable_Energy_LV.pdf

[3] Central Statistical Bureau of Latvia [Online]. [Accessed 02.05.2019]. Available: https://www.csb.gov.lv/en/statistika/db

[4] Latvian Renewable Energy federation. Saules enerğija (Sun energy) [Online]. [Accessed 02.05.2019]. Available: https://www.laef.lv/lv/saule/

[5] Papildus informācija par solāro panel̦u veiktspēju (Additional information on Photovoltaic Panel efficiency) [Online]. [Accessed 02.05.2019]. Available: http://www.ingdep.lv/lv/fotovoltazas-panelu-veiktspeja (in Latvian) 
[6] Sampaio P. G. V., Gonzalez M. O. A. Photovoltaic solar energy: Conceptual framework. Renewable and Sustainable Energy Reviews 2017:74:590-601. doi:10.1016/j.rser.2017.02.081

[7] Saules enerǵijas izmantošanas iespējas Latvijā (Possibilities of solar energy utilization in Latvia) [Online]. [Accessed 02.05.2019]. Available: http://solenergo.lv/raksti-un-noderiga-informacija/saules-energijas-izmantosanas-iespejaslatvija (in Latvian)

[8] Lauka D., Blumberga D., Grabaak I., Amundsen J. S. Results of Investment Analysis in Power Transmission in Latvia and Lithuania. Energy Procedia 2016:95:243-248. doi:10.1016/j.egypro.2016.09.060

[9] Elektrum pieredze saules paneḷu tirdzniecībā (Elektrum experience in solar panel trade) [Online]. [Accessed 2.05.2019]. Available: https://www.youtube.com/watch?v=fMwy8uEnpP8 (in Latvian)

[10] Blumberga A., Lauka D., Barisa A., Blumberga D. Modelling the Baltic power system till 2050. Energy Conversion and Management 2016:107:67-75. doi:10.1016/j.enconman.2015.09.005

[11] Duntes muižā atklāj Saules dārzu (Dunte Manor opens the Sun Garden.) [Online]. [Accessed 02.05.2019]. Available: http://www.salacgriva.lv/lat/salacgrivas_novads/?text_id=15581 (in Latvian)

[12] Lauka D., Pakere I., Blumberga D. First solar powerplant in Latvia. Analysis of operational data. Energy Procedia 2018:147:162-165. doi:10.1016/j.egypro.2018.07.049

[13] Reducing carbon emissions: EU targets and measures [Online]. [Accessed 02.05.2019]. Available: https://www.europarl.europa.eu/news/en/headlines/society/20180305STO99003/reducing-carbon-emissions-eutargets-and-measures

[14] Bariss U., Bazbauers G., Blumberga A., Bumberga D. System Dynamics Modeling of Households' Electricity Consumption and Cost-Income Ratio: a Case Study of Latvia. Environmental and Climate Technologies 2017:20(1):36-50. doi:10.1515/rtuect-2017-0009

[15] Latosov E., Volkova A., Siirde A., Kurnitski J., Thalfelft M. Methodological Approach to Determening the Effect of Parallel Energy Consumption of District Heating System. Environmental and Climate Technologies 2017:19(1):4-14. doi:10.1515/rtuect-2017-0001

[16] Enerǵētikas attīstības pamatnostādnes 2016.-2020. gadam (Energy Development Guidelines 2016-2020) [Online]. [Accessed 02.05.2019]. Available: https://em.gov.lv/files/ministrija/EM_080216_pamatnost.docx (in Latvian)

[17] Blumberga A., et al. Achieving sustainability in non-ETS sectors using system dynamics modelling practice. Chemical Engineering Transactions 2015:45:871-876. doi:10.3303/CET1545146

[18] Samejima M., Shimizu Y., Akiyoshi M., Komoda N. SWOT Analysis Support Tool for Verification of Business Strategy. Presented at the 2006 IEEE International Conference on Computational Cybernetics, Budapest, Hungary, 2006.

[19] Dyson R. G. Strategic development and SWOT analysis at the University of Warwick. European Journal of Operational Research 2004:152(3):631-640. doi:10.1016/S0377-2217(03)00062-6 